\title{
Hypopituitarism in the elderly in the presence of elevated thyroid stimulating hormone levels
}

\author{
Timothy Beringer, ${ }^{1}$ Brian McClements, ${ }^{1}$ Ivan Weir, ${ }^{1}$ David Gilmore ${ }^{1}$ and \\ Laurence Kennedy ${ }^{2}$ \\ ${ }^{1}$ Geriatric Medical Unit and ${ }^{2}$ The Sir George E. Clark Metabolic Unit, Royal Victoria Hospital, Belfast \\ BT12 6BA, UK.
}

\begin{abstract}
Summary: Two cases of primary hypothyroidism with hypopituitarism in elderly patients are reported. The elevated levels of thyroid stimulating hormone led to delay in the recognition of accompanying pituitary failure. Elderly patients should not be commenced on thyroxine replacement therapy until the possibility of hypopituitarism and cortisol deficiency has been excluded.
\end{abstract}

\section{Introduction}

Primary hypothyroidism is a common condition in the elderly, whereas hypothyroidism secondary to hypopituitarism is much less common. ${ }^{1}$ It has however been suggested that it may occur more frequently than previously suspected. ${ }^{2}$ Since effective replacement therapy is available, undiagnosed or untreated patients may be deprived of considerable benefit.

\section{Case reports}

Case 1

A 70 year old widow presented with lethargy and disorientation. She was found to have a low serum free thyroxine of $4.9 \mathrm{pmol} / 1$ (normal 9-26) with an elevated thyroid stimulating hormone (TSH) of $14.7 \mathrm{mU} / 1$ (normal $0-5$ ). The serum sodium was $116 \mathrm{mmol} / 1$. A diagnosis of primary hypothyroidism was made, and after treatment with thyroxine and fluid restriction her sodium rose to $129 \mathrm{mmol} / \mathrm{l}$. She was discharged home to continue thyroxine $100 \mu \mathrm{g}$ daily and the TSH subsequently fell to $0.8 \mathrm{mU} / \mathrm{l}$. After initial improvement, further gradual deterioration occurred with loss of mobility and she was

Correspondence: T.R.O. Beringer, M.D., M.R.C.P.

Accepted: 11 May 1988 subsequently transferred 5 months later to our unit for long-term geriatric care. She remained alert but complained of lethargy. Marked pallor was evident with absent pubic and axillary hair. She was confined to bed with $80^{\circ}$ flexion contractures of both knees. Visual fields were full to confrontation. There was a history of haemorrhage after childbirth with subsequent amenorrhoea from the age of 42 . The serum sodium was again low at $123 \mathrm{mmol} / \mathrm{l}$ with a normal glucose of $4.3 \mathrm{mmol} / \mathrm{l}$. Plasma cortisol at $07.00 \mathrm{~h}$ was $54 \mathrm{nmol} / 1$ (normal 140-690), at $22.00 \mathrm{~h} 59 \mathrm{nmol} / 1$, rising 60 minutes after tetracosactrin (Synacthen) $250 \mu \mathrm{g}$ to $470 \mathrm{nmol} / 1$. An insulin stress test resulted in a subnormal response with a peak cortisol of $206 \mathrm{nmol} / 1$ with a low basal growth hormone of $0.6 \mathrm{mU} / 1$ and stimulated level of $2.6 \mathrm{mU} / 1$. Diminished basal and stimulated levels of follicle stimulating hormone and luteinizing hormone were also present. Basal serum prolactin was $105 \mathrm{mU} / 1$ (normal <300). Thyroglobulin and adrenal antibodies were negative with a thyroid microsomal titre of 1600 (significant >6400). Computed tomography revealed a partially empty sella with cisternal invagination.

A dramatic response followed the introduction of hydrocortisone replacement therapy with resolution of the hyponatraemia, lethargy and, gradually, the knee contractures. She regained full independence enabling her to return to her home.

(C) The Fellowship of Postgraduate Medicine, 1988 


\section{Case 2}

A 75 year old retired merchant seaman presented to hospital with tiredness and malaise. Investigations revealed a free thyroxine of $2 \mathrm{pmol} / \mathrm{l}$ with TSH of $50 \mathrm{mU} / \mathrm{l}$. The thyroglobulin antibody titre was 1280 (significant $>640$ ) and microsomal antibody titre 1600. A diagnosis of primary hypothyroidism was made and the patient discharged from hospital on thyroxine $100 \mu \mathrm{g}$ daily, with a subsequent fall of TSH to $<1 \mathrm{mU} / 1$. Six weeks later he was referred to us for geriatric care with a history of recurrent falls at home and confusion. Further assessment confirmed the presence of a confusion with a mental test score of $4 / 10,{ }^{3}$ postural hypotension with a blood pressure of $100 / 40 \mathrm{mmHg}$ lying, $60 /$ unrecordable standing, nausea and pallor. There was sparse pubic and axillary hair with associated poor beard growth. No history of major head injury was obtained and visual fields were full to confrontation. Plasma cortisol at $07.00 \mathrm{~h}$ was $42 \mathrm{nmol} / 1$, at $22.00 \mathrm{~h} 30 \mathrm{nmol} / 1$ and 60 minutes after tetracosactrin $254 \mathrm{nmol} / \mathrm{l}$. The plasma adrenocorticotrophic hormone level of $38 \mathrm{ng} / \mathrm{l}$ was inappropriately low. Adrenal antibodies were not detected. The basal serum prolactin was $492 \mathrm{mU} / 1$ and testosterone $0.9 \mathrm{nmol} / 1$. Computed tomography of the pituitary fossa was normal. Marked clinical improvement followed the introduction of hydrocortisone replacement therapy with resolution of the confusion and postural hypotension. $\mathrm{He}$ regained full independence allowing discharge home.

\section{Discussion}

Primary hypothyroidism is a common condition it. the elderly while hypopituitarism is much less so. We have demonstrated that partial hypopituitarism and primary hypothyroidism may occur together. Selective loss of anterior pituitary function may develop with preserved TSH response to primary thyroid insufficiency despite deficiency of adrenocorticotrophic hormone, growth hormone and

\section{References}

1. Hodkinson, M. Thyroid disorders. In: Exton-Smith, A.N. \& Caird, F.I. (eds) Metabolic and Nutritional Disorders in the Elderly. John Wright, Bristol, 1980, pp 211-219.

2. Belchetz, P.E. Idiopathic hypopituitarism in the elderly. Br Med J 1985, 291: 247-248.

3. Qureshi, K.N. \& Hodkinson, H.M. Evaluation of a ten-question mental test in institutionalised elderly. Age Ageing 1974, 3: 152-157.

4. Faglia, G., Bitensky, L., Pinchera, A. et al. Thyrotropin secretion in patients with central hypothyroidism: evidence for reduced biological activity of immunoreactive thyrotropin. $J$ Clin Endocrinol Metab 1979, 48: 989-998. gonadotrophins. Thus, TSH levels may be elevated in the presence of hypopituitarism due to accompanying primary hypothyroidism. Mild elevation of immunoreactive TSH levels may occur in secondary hypothyroidism due to secretion of TSH with reduced biological activity, though the levels observed were always $<10 \mathrm{mU} / 1 .{ }^{4}$ Regardless of the cause of elevation of TSH levels, careful clinical examination of elderly hypothyroid patients for signs of hypopituitarism, in addition to appropriate investigation, will correctly identify the need for cortisone replacement as well as thyroxine replacement therapy. The clinical findings of postural hypotension, contractures of the knees and hyponatraemia have been highlighted previously. ${ }^{2,5}$

Without pathological examination the aetiology of the hypopituitarism in these cases remains unclear. No microadenomata were identified by computed tomography and an autonomous TSH secreting adenoma may be excluded by the fall in TSH levels following thyroxine replacement therapy. There was no radiological evidence of pituitary involvement by a systemic granulomatous condition such as sarcoidosis or tuberculosis. The history of postpartum haemorrhage in Case 1 is in keeping with Sheehan's syndrome, supported by the reduced volume of tissue within the sella turcica. Case 2 could be explained by hypothalamic or pituitary disease with a vascular aetiology related to atheroma. However, previous case reports of lymphocytic or granulomatous hypophysitis ${ }^{6-8}$ with concomitant primary hypothyroidism support an alternative autoimmune aetiology, providing a common link between the two affected organs. No clinical evidence of a more widespread autoimmune polyendocrinopathy was identified in our subjects.

The presence of an elevated TSH level in association with lowered thyroid hormone secretion cannot be assumed to indicate intact anterior pituitary function. These cases highlight the need to consider carefully the possibility of hypopituitarism in elderly patients with apparent primary hypothyroidism before commencing thyroxine replacement therapy.

5. Blandford, R.L., Samanta, A.K., Burden, A.C. \& Rosenthal, F.D. Muscle contractures associated with glucocorticoid deficiency. Br Med J 1985, 291: 127-128.

6. Goudie, R.B. \& Pinkerton, P.H. Anterior hypophysitis and Hashimoto's disease in a young woman. $J$ Pathol Bact 1962, 83: 584-585.

7. Hume, R. \& Roberts, G.H. Hypophysitis and hypopituitarism: report of a case. Br Med J 1967, 2: 548550.

8. Ludmerer, K.M. \& Kissane, J.M. Primary hypothyroidism and hypopituitarism in a young woman. Am J Med 1984, 77: 319-330. 